että tuhti paketti kiinnostaa lähinnä alan tutkijoita, ja harva ehkä lukee paksun teoksen alusta loppuun. Se onkin jäsennetty selkeästi niin, että on helppo tarttua tiettyyn osaan tai vaikkapa yksittäiseen lukuun. Teoksen saatavuus on myös tehty helpoksi, sillä se on, kiitos COST-rahoituksen, avoimesti saatavana ja ladattavana luku kerrallaan e-kirjana osoitteessa: https://www.elgaronline. com/view/9781786432100.xml

\section{ONKO PREKARISAATIO VAIN TARUA?}

Tuukka Niemi: MSc, tohtorikoulutettava, Helsingin yliopisto

Pasi Pyöriä (toim.): Työelämän myytit ja todellisuus. Gaudeamus, Helsinki. 2017, $236 \mathrm{~s}$.

Työelämän myytit ja todellisuus on Pasi Pyöriän toimittama artikkelikokoelma. Pyörïä on viime vuosina ollut näkyvä osa sitä suomalaisen työelämän tutkimuksen koulukuntaa, joka on kyseenalaistanut paljon puhutun työelämän murroksen ja työhön liittyvän epävarmuuden yleistymisen eli prekarisoitumisen. Tähän tutkijakastiin kuulunevat myös teoksen kirjoittajat, jotka ovat pääosin Jyväskylän ja Tampereen yliopistoilla toimivia tutkijoita. Vaikka kirjoittajia on peräti 15, Pyöriän kontribuutio kirjaan on näkyvä.Tämän selittänee osittain se, että teos pohjautuu hänen Tampereen yliopistolla pitämäänsä luentoseminaariin.

Kirjan lähtökohtana ovat "myytit", joiden väitetään dominoivan työelämään liittyvää julkista keskustelua Suomessa. Vaikka myytti-sanaa ei teoksessa varsinaisesti määritellä, kuvataan sillä yleisiä, usein median tukemia uskomuksia Suomen nykyisestä työelämästä. Nämä uskomukset koskevat pääosin näkemystä työelämän murroksesta, joka on johtanut erityisesti työelämän entistä epävarmempaan ja sirpaleisempaan luonteeseen. Kirjan luettelo työelämään liittyvistä myyteistä on kuitenkin tätä kattavampi, minkä seurauksena kirjassa tarkastellaan työelämää hyvinkin monella mittarilla. Myyttejä on esitelty ja tarkasteltu vuorotellen yksittäisissä luvuissa: niitä ovat muun muassa epätyypillisten työsuhteiden yleistyminen, nuorten työmoraalin ja yleisen ansiotyöhön sitoutumisen heikkeneminen, "24/7-yhteiskunta", sukupuolten tasa-arvo työmarkkinoilla, työtaistelujen ongelmallisuus sekä työn ja perheen hankaloitunut yhteensovittaminen.

Myyttejä pyritään luku toisensa jälkeen kyseenalaistamaan pitkälti mittavilla aineistoilla kerätyillä työvoima- ja työolotilastoilla. Näillä kirjoittajat pyrkivät paljastamaan kirjan otsikossa luvatun työelämän "todellisuuden", eli sen, että yleisesti uskotut myytit ovat vain sitä: myyttejä. Tässä kirja onnistuu periaatteessa oikein hyvin. Artikkeleissa käytetty aineisto todellakin antaa ymmärtää, että työn murrosta ja nykytilannetta on monesta näkökulmasta liioiteltu tai kärjistetty. Vakituisten työsuhteiden osuus palkkatyöstä on pysynyt vuosien saatossa miltei samana, työhön sitoutuminen on entisellä tasollaan, epätyypilliset työvuorot ovat edelleen harvinaisia, ja niin edelleen. 
Kirjan johdannossa annetaan ymmärtää, että moni tarkastelluista myyteistä juontaa juurensa prekarisaatiokeskusteluun. Pyöriä ja Satu Ojala, yksi kirjoittajista, perustelevat, että prekarisaatioteesi on saanut suosiota osakseen laadullisella otteella kehitetyllä "aikalaisdiagnoosilla". Tällä he tarkoittavat analyysiä yhteiskunnallisista muutoksista nykykapitalismin seurauksena. Näihin kuuluvat sekä työelämän murrokset että laajemmat prosessit, kuten kansalaisten eriarvoistuminen ja sosiaaliturvan heikkeneminen.

Voidaan kysyä, miksi myyttejä ei rajattu juuri prekarisaatiokeskusteluun. Taustalla ollut luentoseminaari lienee yksi selitys, mikä heijastuukin kirjassa työelämän tarkastelun kattavuutena, mutta samalla selvän tutkimuskysymyksen ja koherentin argumentin puutteena. Tietyt tarkastellut myytit, kuten sukupuolten välinen tasa-arvo työelämässä, lytätään kirjassa vakuuttavasti, mutta samalla ne jäävät sivuun kirjan prekarisaatioon liittyvästä fokuksesta. Tästä syystä työelämän tarkastelu on turhankin monipuolinen. Siinä missä lähes jokaisen mahdollisen työelämän "myytin" kumoaminen näkyy kirjan toteutuksessa, on sen tunnistettava teema prekarisaatioteesin kyseenalaistaminen.

Kirjoittajat eivät kuitenkaan täysin kiistä työn prekarisaation olemassaoloa. Muun muassa koetun epävarmuuden lisääntyminen työelämässä osana prekarisaatiota pidetään kirjassa tosiasiana, joskin liioiteltuna. Kirjassa kuitenkin asetetaan prekarisaatiota korostava aikalaisdiagnoosi vastakkain makrotason työmarkkinatilastojen tutkimuksen kanssa - kirjoittajat kertovat edustavansa jälkimmäistä. Tästä työelämän tutkimus- ja analyysitapojen vastakkainasettelusta kumpuaa kysymys, voidaanko prekarisaatioteesi ja näkemys työelämän merkittävästä mullistuksesta ongelmitta redusoida tilastoihin.

Tukeakseen argumenttejaan osa kirjoittajista tulkitsee tilastoja hieman sinisilmäisesti, ottamatta huomioon niiden kyvyttömyyttä kertoa koko totuutta. Esimerkiksi teesi 24/7-yhteiskunnasta esitellään näkemyksenä työn ja arjen sekoittumisesta yhteiskunnassa, jossa työ rajoittuu harvemmin työsopimusten määrittämiin työaikoihin. Kuitenkin luvussa tarkastellaan nimenomaan työsopimuksiin perustuvia tilastoja epätyypillisten työaikojen määrästä. Toki tilastojen osoittama epätyypillisten työaikojen lisääntymisen vaatimattomuus on yllättävä ja alleviivattava havainto (vaikka aineistoa tuoreempi kauppojen aukioloaikojen vapautus vuoden 2016 alussa olisikin voitu mainita). Mutta kuten useassa kirjan luvussa, kirjoittajat sortuvat turhan jyrkkiin johtopäätöksiin tilastojen valossa.

Kussakin luvussa tarkasteltava myytti esitellään viitaten muutamiin lähteisiin, ennen sen tilastollista kumoamista. Tämä tuo kirjaan yhtenäisyyttä, mutta se myös ajoittain heikentää argumentaatiota. Tilastojen vakuuttavuudesta huolimatta osa kirjan luvuista ei aivan onnistu luomaan uskottavaa käsitystä siitä, että kyseessä todella on laajalti uskottu myytti. Prekarisaatioteesin vankimmatkaan puoltajat tuskin uskovat, että pätkätyöläiset ovat säännönomaisesti huonovointisia, tai että työtä ja perhettä on enää mahdotonta sovittaa 
onnistuneesti yhteen. Tämä on sääli, sillä myyttien taustoitus sosiologisesta ja osin historiallisesta perspektiivistä artikkelien alussa tuo kirjan tilastovetoisuudelle oivaa tasapainoa.

Jälkisanoissa on tervetullutta pohdiskelua keskusteluun liittyvistä sosiaalipoliittisista avauksista ja vaihtoehdoista. Jyrkiltä kannanotoilta vältytään huolimatta keskustelun poliittisesta latautuneisuudesta (ks. esim. perustulokeskustelu). Kirja myös välttää harvinaisen hyvin sortumasta poleemisiin väitöksiin tukeakseen näkökulmaansa, mutta toisaalta sosiaalipoliittinen keskustelu jää hieman yleiselle ja varovaiselle tasolle. Kirjassa esimerkiksi sivuutetaan melkein täysin tietyt sosiaalipolitiikkaan liittyvät tekijät, jotka voidaan tulkita osaksi työn prekarisaatiota. Näitä ovat esimerkiksi työttömiä entistä ankarammin työnhakuun patistava työvoimapolitiikka ja pitkäaikaistyöttömien heikentyneet turvaverkot. Toki kirjan jälkisanoissa mainitaan kyseisen politiikan vaarat ja korostetaan työttömyydestä johtuvan syrjäytymisen ehkäisemisen tärkeyttä, mutta tätä keskustelua olisi voitu syventää. Samoin hieman syvällisempi pohdiskelu prekarisaation liioittelun syistä, peräti oman kokonaisen luvun turvin, olisi tuonut kirjaan särmää.

Kirja on kokonaisuudessaan hyödyllinen, melkeinpä olennainen lisäys suomalaiseen työelämän tutkimuskirjallisuuteen. Teos toimii kattavana katsauksena työelämän kiisteltyihin näkökohtiin. Samalla kirjoittajat tuovat näkökohtiin uutta valoa rikkaan tilastoaineiston turvin. Ajoittain ylenmääräisestä myytinmurtaja-asentees- taan huolimatta kirjoittajat onnistuvat haastamaan yleisiä, sosiaalipolitiikan tutkijoidenkin keskuudessa suosittuja, käsityksiä työelämän nykytilanteesta. Sujuvan kielen ja selkeiden taulukkojen välisen sopusoinnun ansiosta kirja luultavasti vetoaa jokaiseen aiheesta ja prekarisaatiokeskustelusta kiinnostuneeseen.

\section{MYÖTÄTUNTO - VIISISÄRMÄINEN MAHDOLLISUUKSIEN MIEKKA}

Minna Mattila-Aalto: $V T T, K M$, $k e-$ hittämispäällikkö, Työtehoseura

Elisa Aaltola \& Sami Keto: Empatia. Myötäelämisen tiede. Into Kustannus, Helsinki. 2017, 330 s.

Elisa Aaltola ja Sami Keto tarttuvat teoksessaan yhteiskunnallisesti aina ajankohtaiseen myötäelämiseen. $\mathrm{He}$ avaavat moniulotteisen käsityksen myötätunnon merkityksistä elintärkeässä asiassa: miten ihmiset kykenevät rakentamaan yhteenkuuluvuutta tuottavia ja elämää kannattelevia vastavuoroisia suhteita nyt ja tulevaisuudessa?

Aaltola avaa myötätunnon monisärmäisyyttä esittelemällä ensin empatian viisi ulottuvuutta: projektiivisen ja simuloivan, kognitiivisen, affektiivisen, ruumiillisen ja lopulta reflektiivisen empatian. Hän kuvaa lukijalle seikkaperäisesti kunkin empatian muodon "hyvässä ja pahassa". Lukijalle muodostuu käsitys siitä, minkälaisia keinoja projektio ja simulaatio ovat yrittäessämme hahmottaa toisiamme entistä kattavammin, miten kognitiivinen empatia auttaa meitä lukemaan toisten mieltä 